\title{
Multiple ontologies of water: Politics, conflict and implications for governance
}

\section{JULIAN S. YATES}

Corresponding Author: julian.yates@monash.edu

\section{LEILA M. HARRIS}

NICOLE J. WILSON

University of British Columbia, Date 2015

Final version: Yates, J., N. Wilson \& L. Harris. (In press, 2017). Multiple Ontologies of Water: politics, conflict and implications for governance. Environment and Planning D: Society and Space. DOI: 10.1177/0263775817700395.

Citations of this work should use the final version as noted above 


\section{ABSTRACT}

We ask what it would mean to take seriously the possibility of multiple water ontologies, and what the implications of this would be for water governance in theory and practice. We contribute to a growing body of literature that is reformulating understanding of human- water relations and refocusing on the fundamental question of what water 'is'. Interrogating the political-ontological 'problem space' of water governance, we explore a series of ontological disjunctures that persist. Rather than seeking to characterize any individual ontology, we focus on the limitations of silencing diverse ontologies, and on the potential of embracing ontological plurality in water governance. Exploring these ideas in relation to examples from the Canadian province of British Columbia, we develop the notion of ontological conjunctures, which is based on networked dialogue among multiple water ontologies and which points to forms of water governance that begin to embrace such a dialogue. We highlight water as siwlkw and the processual concept of En'owkin as examples of this approach, emphasizing the significance of cross-pollinating scholarship across debates on water and multiple ontologies.

Keywords: Canada, First Nations, Indigenous governance, ontological politics, ontology, water governance 


\section{INTRODUCTION}

Recent attention has been paid to the promise and politics of 'a multiplicity of worlds animated in different ways' (Blaser, 2014: 49). This work has challenged the assumption of a singular world (of one material reality that is 'out-there', fixed, knowable, and potentially manageable by humans according to related knowledge hierarchies), proposing that we pay serious attention to the possibility that there are diverse ways of being within and interacting with multiple worlds. In a set of recent contributions, for example, Mario Blaser (2009a, 2009b, 2013, 2014) has drawn attention to the limitations of environmental policies that dismiss ontological dimensions as cultural constructions. Drawing on a sustainable hunting programme involving the Yshiro people of Paraguay, Blaser (2009b) illustrated how conservation rationales that support hunting and fishing restrictions do not reflect Yshiro human-animal relations. The imposition of modernist conservation rationales and a dismissal of Yshiro relational ontologies - which revolve around mutual co-dependence among all entities within the yrmo (territory) - contributed to the failure of the conservation effort. Given the wilful refusal to acknowledge Yshiro ontologies, Blaser concluded that more attention to these ontological processes is needed:

The conflict that ensued from the hunting program highlights the need to understand these kinds of situations from a ... perspective that focuses on the power dynamics produced in the encounter between the dominant modern ontology and Indigenous ontologies as they are embodied in concrete practices (Blaser, 2009b: 18, emphasis added).

In this paper, we aim to reveal how similar ontological processes are shaping water governance, focusing on examples from the province of British Columbia in Canada. We ask what the implications would be to take seriously the possibility and politics of a multiplicity of water-related worlds, highlighting multiple water realities and ways of beingwith-water, not just different perceptions of or knowledge systems tied to water's (singular) material existence. Similar lines of enquiry have been made in other contexts, such as in relation to: hunter-and herder-animal relations (Blaser, 2009b; Lorimer, 2016; Nadasdy, 2007); human-fish relations (Todd, 2014); sentient other-thanhuman beings otherwise considered 'inanimate', including trees, mountains and glaciers (Bird Rose, 2008; Cruikshank, 2004; de La Cadena, 2010, 2015); environmental change and assessment (Forsyth and Levidow, 2015; Nightingale, 2016); and the body politics of medicine (Mol, 1999; Mol et al., 2002).

By exploring the implications of the ontological turn for water governance debates, however, we contribute most directly to a growing body of literature that is reformulating our understanding of the nature of water and human-water relations (e.g. Boelens, 2014; Chen et al., 2013b; Krause and Strang, 2016; Linton, 2010; Linton and Budds, 2014; Strang, 2004; Wagner, 2013; Wilson, 2014). The notion of multiple ontologies of water was raised in a recent special issue in Social Studies of Science, which explored how water shapes our social worlds through multiple material engagements and assemblages (Barnes and Alatout, 2012). Bear (2012) makes a similar argument, drawing water's agency together with that of other non-human actors 
to highlight the multi-dimensional ontology of seas and oceans. While these assemblage approaches (including those that focus mostly on material agency, see Bear and Bull, 2011) are productive for uncovering multiple dimensions of water's biophysical makeup in diverse social settings, we focus on the political processes of ontological entanglement and disentanglement, highlighting water ontologies as a site of political contest (cf. Lavau's notion of ontological cleaving, which we discuss below Lavau, 2013). Likewise, we distinguish our approach from Steinberg and Peters' (2015) recent conceptualization of 'wet ontologies', in which they use metaphors such as liquidity, mixing and volume to bring new insights to political-geographic issues such as territory and boundedness. We focus instead on examples of political-ontological friction, showing how and why ontological conflicts are currently important in British Columbia, Canada. We do so by 'de-centering agency away from humans' (Bakker, 2012: 621) to speak directly to the materiality and agency of water as a living being.

In focusing on the political spaces where water ontologies meet, our approach is not designed to uncover or depict any individual ontology; rather, it is an approach that focuses on the practical and political implications of enabling or silencing diverse worlds, and calling into question the ontological assumptions that underpin dominant forms of water governance. We follow Blaser in focussing on the 'problem space' where multiple water worlds intersect, and by paying attention the political processes and implications that emerge as they intermingle (Blaser, 2014). Issues such as water treatment, for example, are too frequently reduced to the domain of technical experts, who often enact various modernist ontologies of water-as-a-resource, relegating emergent challenges to the status of cultural perceptions and/or cultural barriers. In exploring several examples of this type, we offer the kind of 'situated questioning' of ontological hegemony that Joronen and Ha"kli (2016: 14) have called for by highlighting that these conflicts are not necessarily about a lack of technical or scientific understanding of water-related issues, and they are not simply about a lack of dialogue or agreement about how water should be used or managed. Rather, they are ontological disjunctures - conflicts over the very essence and being of water.

Notwithstanding the aforementioned contributions, and despite the fact that Indigenous and other peoples often cast as 'outside' of modernity have long stressed multiple and relational ontologies (Kesler, n.d.; Sundberg, 2014), the lines of enquiry we present here remain under-unexplored in water-related research. We aim to raise awareness of these issues, suggesting that engaging substantially with the implications of a politics of multiple water ontologies might provide a better understanding of the conflicts that emerge when particular water governance and management options are proposed and - at times - challenged. This sensitivity is especially needed in settlercolonial contexts where modern water ontologies remain hegemonic. As our examples reveal, the effects of ontological hegemony and contestation are often acutely experienced among Indigenous populations. The interventions here are therefore helpful not only for academic discussions, but also serve to further the project of decolonizing water governance.

We begin by clarifying conceptual issues related to multiple ontologies and their political intersection, before exploring how theoretical work and empirical examples within the water governance literature illustrate the significance of ontological concerns. We then turn to several specific examples to clarify these insights, focusing on drinking 
water provision among rural and First Nations communities in the Canadian province of British Columbia. ${ }^{1}$ In the penultimate section we identify tentative proposals for advancing water governance approaches based on a networked dialogue among multiple water ontologies, before concluding with how our discussion advances theorizations of and practical approaches to water and its governance, as well as debates on ontology.

\section{MULTIPLE WATER ONTOLOGIES: (WHY) DO THEY MATTER?}

Analytic frames such as 'ontological politics' (Mol, 1999), 'ontological assumptions' (Nadasdy, 2007), 'ontological discourses' (Barad, 2007), 'ontological conflict' (Blaser, 2013), 'ontological pluralism' (Howitt and Suchet-Pearson, 2006) and 'political ontology' (Blaser, 2009a, 2009b, 2014) variously explore how multiple worlds intersect, with diverse political consequences. Together, these interventions constitute part of the so-called 'ontological turn', which describes a body of work that takes the nature of being (ontology/ontologies) as the primary focus of enquiry. ${ }^{2}$ While the ontological turn is far from a uniform intellectual project (Joronen and Ha"kli, 2016), many accounts build on Annemarie Mol's (1999) assertion that processes of doing reality are historically, culturally and materially embedded. Reality varies; it is enacted as a process, rather than simply observed (Mol et al., 2002). As such, it is also inevitably political, as some ontological enactments are prioritized over others. Ontological politics, in this sense, refers to the varied processes of asserting particular worlds or enacting realities.

Ontological politics has been taken up as an analytical starting point in a range of fields. To draw on a few examples, Paul Nadasdy (2007) has made a similar point to Blaser in illustrating how the ontological assumptions of scientists attempting to implement wildlife conservation programmes in Northern Canada dismissed Indigenous ontologies of hunter-animal reciprocity, thereby rejecting them from management plans and disempowering Indigenous peoples and their knowledge. Ontological politics has also helped us to expand what can be considered as animate beings. Marisol de la Cadena (2010) has shown that, in the Andes, other-than-human sentient entities (such as living mountains) are brought into political debates in order to challenge dominant conceptions of nature and environmental politics. Contestation subsequently emerges, as groups unfamiliar with ontologies of mountains as living beings, for example, are unable to understand that humans can have political, emotional and existential obligations to these 'sentient entities' (de la Cadena, 2015). For de la Cadena (2015), these points of contestation reflect partial connections between worlds, which Eric Hirsch (2017) brilliantly illustrates through a case of everyday ontological politics and mining in Peru's southern Andes. These partial connections also create opportunities for mutual political dialogue - a point we return to in our penultimate section. ${ }^{3}$

We take these insights on multiple ontologies as a starting point for analysis, asking - to paraphrase Blaser - whether the water of scientists, engineers and government agencies reflects just one possible reality of water. If so, what might it mean to take seriously diverse waterworlds, and what might this lend to our analyses and 
explanations of water politics and governance? Moreover, what can the study of water add to debates on the conjunction of politics and ontology? We begin with water as an animate being, which brings useful insights by virtue of water's flows and its role (as we clarify below) as lifeblood - as an always dynamic process, always producing change, and essential to life. While recent accounts have pointed to the ways in which multiple, animate water worlds emerge through performative practices (see Neimanis, 2013; Stensrud, 2016), we focus on the ontological question of water's inherent multiplicity. The diverse and fluid materiality of water, we argue, is important for understanding why ontological disjunctures emerge and why conjunctures remain possible.

We therefore aim to build on existing contributions in the field that have begun to ask similar questions about various enactments and different understanding of water. Work on hydro-social relations and their attendant politics, for example, is partly about recognizing water as connecting and mediating social and political worlds. This work moves away from narrow understanding of water as a compound or resource $(\mathrm{H} 2 \mathrm{O})$, to conceive it as a dynamic, relational process that mediates between subjects and objects (Linton, 2012). Concepts such as 'waterscapes' or 'water worlds' signal that water is a socio-political and ecological integrator in ways that extend beyond understanding water as simply comprised of chemical constituents (Barnes and Alatout, 2012; Hastrup and Hastrup, 2016; Linton and Budds, 2014; Loftus, 2007; Swyngedouw, 1999).

Other commentators have explored elements of this terrain in terms of the emergence of hegemonic water-related practices, which destabilize and marginalize other governance possibilities (Baker, 2013; Harris, 2015; Sneddon, 2013). These works focus on how certain approaches and practices associated with governing water become entrenched, occluding alternative water paradigms. Lyla Mehta (2013), for example, illustrated how hegemonic models of water relating to large-scale dam development in India sever the existing hydro-social worlds of project-affected people. In the Canadian context, Andrew Biro (2013) has shown how a similar technologically driven ontology of water has displaced a historic and place-specific ontology of hydrosocial adaptiveness.

These contributions challenge key norms in water governance. From Jamie Linton's (2010) treatment of the question 'what is water?', to Astrida Neimanis' (2013) feminist water subjectivities and Jennifer Spiegel's (2013) work on ontologically-derived hydrologics, much has been done recently to 'actively question habitual instrumentalizations of water' (Chen et al., 2013a: 4). This work has helped us to 'pay more attention to the waters that are too often relegated to the passive backdrop of our lives', as we become more attuned to the 'global flows of political, social, cultural, economic and colonial planetary power' that make up our watery bodies and subjectivities (Neimanis, 2013: 28).

Questions of ontology are therefore increasingly of central concern, and yet have only partially been addressed to date. Rutgerd Boelens (2014), for example, has shown how diverse water worlds have been subjugated by dominant socio-natural orders, which position humans and non-humans within hierarchical hydrosocial patterns. Stephanie Lavau (2013) also invites attention to ontology, focusing not just on artificial separations and enforced disjunctures, but also on how ontological multiplicity can be drawn together (see discussion below on ontological conjunctures). Lavau used the term 'ontological cleaving', deploying the dual meaning of the word (to cleave) to 
highlight the intermingling of ontological difference. Using the example of the Goulburn River in Australia, Lavau shows how management ontologies associated with predictable 'natural flows' of 'environmental water' are first cleaved apart, before being brought together again in the political-material orderings of sustainable river management. 'The problem of difference', she argues, 'becomes one of multiple realities, and how these are made to coexist' (Lavau, 2013: 524), indicating that entangled river realities converge and diverge in spatially patterned ways according to the ways in which diverse social groups engage with water's materiality.

We are interested in these moments of convergence and divergence as they take place within what Astrid Stensrud (2016: 95) called 'political field[s] of negotiation'. In what follows, we explore one such political field of negotiation, highlighting political struggles over water's materiality and ontology. This focus helps us to rethink ideas about 'the specificities of water itself - its chemical properties, symbolic value, and everyday use' (Li, 2013: 19). As we explain through our examples, these specificities of water - and the very nature of water as a living being - emerge as the ontological site for political negotiation, creating both ontological disjunctures and the potential for ontological conjunctures within the political processes associated with water governance.

\section{HYDRO-ONTOLOGICAL CONTESTATION IN BC}

Our work on water governance in British Columbia and elsewhere in Canada has highlighted several contestations that we argue could benefit from close examination through a politicalontological lens. Such attention includes a recognition of how ontological disjunctures might be contributing to ongoing conflicts and the silencing of diverse water ontologies. Our two linked examples illustrate this point. First, we explore the hierarchical ordering of water ontologies and a related prioritization of drinking water, which separates and isolates water according to its (human) uses. Second, we illustrate how such separation creates a (potentially misplaced) justification for 'end-ofpipe' treatment orientations, which work against long-standing ontologies of hydrosocial connection that are arguably more consistent with the kinds of source-water protection approaches increasingly in demand. Both of these examples fit within technical paradigms of water and its governance, which often override and deny alternative ontologies of water as a being in itself. This domination has been exposed elsewhere in the literature on water governance, as some scholars have illustrated the influence of Enlightenment philosophies on our water management paradigms (see, for example: Baker, 2013; Harris et al., 2013; Linton, 2010; Swyngedouw, 1999), while others have elaborated alternative ontologies of water as a living being (Anderson et al., 2013; Simpson et al., 2009).

In contrast to modern ontologies of water-as-a-resource, ontologies of water-aslifeblood lead to an understanding of water as living, interconnected and unbounded.4 While wateras-lifeblood is a notion common across many different Indigenous communities in Canada (see: Anderson et al., 2013; Phare, 2011; Walkem, 2004), we do not mean to imply that it is singular or homogenous across First Nations. Where possible, we refer to these ontologies in the plural so as to reflect their likely diversity 
and multiplicity (without implying equality). More than a cultural construct, water-aslifeblood has been described as a place-based, rights-producing ontology, which connects diverse beings and foregrounds water's health and vitality (Blackstock, 2001). For the Cree elders cited by LaBoucane-Benson et al. (2012: 7), water-as-lifeblood is inextricably (and relationally) linked to human bodily health: 'there is no separation between the water and human beings... We are the water, and the water is us'. In this sense, water as a living being is always in relational connection with humans and other living beings. This ontology is captured by the notions of En'owkin and water as siwlkw, which embrace relational and more-than-human processes of coming-into-being (Armstrong, 2013; Sam, 2008).

In the penultimate section of the paper, we discuss the potential for these concepts to contribute to a dialogue among ontologies. In our examples, however, we focus on contestation and on the argument that a compromise of the vitality of water-aslifeblood will inevitably compromise health and community (including more-than-human) well-being - a process that Simpson et al. (2009) refer to as 'contamination through occupation'. Given these insights (that contamination is simultaneously political and material-ontological), before elaborating our examples it is worth stressing the particular political context of water governance in Canada. If, as Jamie Linton has argued, 'in every case, it is the relation that defines the essence of what water is' (Linton, 2010: 223), then in the case of British Columbia the social relations that define water are largely settler colonial. Consequently, the diverse ontologies of water that we attempt to engage in this paper are often obliged to adhere to recognized forms of representation, which are usually determined by the settler colonial state (at multiple scales) (Hunt, 2014). In BC, ontological representations are conditioned by and inseparable from the policies, legal frameworks, and institutions of settler colonialism, many of which engage with water as a resource that can be secured for current and future (human) needs. While space constraints here prevent a comprehensive discussion of these processes, elsewhere scholars have drawn attention to the ongoing effects of the imposition of English common law doctrine and its political-legal legacies in relation to water, particularly for First Nations (see: Sam and Armstrong, 2013; Simms et al., 2016) and including the way in which it shapes contemporary water governance reforms (such as the BC Water Sustainability Act; see: Jollymore et al., 2017). While attention to these issues is important, here we focus on questions of ontological difference rather than the assertion rights within established legal frameworks. ${ }^{5}$

\section{Example 1: The ontological limits of separating water according to its "uses"}

Recent attention has been paid to the costs of a drinking water focus in water governance. Basdeo and Bharadwaj (2013), for example, have shown how a technical focus and hierarchical ordering of water needs has led to a neglect of many social, cultural and spiritual needs among First Nations. Anishnaabe scholar Deborah McGregor (McGregor, 2012: 11) has stressed this point:

Water is not a single, discrete aspect of the environment; it is part of a greater, interconnected whole. When one considers water, therefore, one 
must consider all that to which water is connected and related [i.e. a relational ontology of water as a living being]. Elders felt current government initiatives around water to be limited and short-sighted. When one considers water, one must consider all that water supports and all that supports water. Therefore, a focus on just drinking water is misguided. It is not in keeping with traditional principles of... the interdependence of all living things. One must also consider, for example, the plants that water nourishes, the fish that live in water, the medicines that grow in or around water, and the animals that drink water.

In a case of developing small-scale water treatment facilities for small communities and First Nations, we have observed cases where drinking water was separated and its infrastructure prioritized over other needs and an interconnected ontology of water-as-lifeblood. This prioritization stems from, and supports, hegemonic ontologies of water-as-a-resource, which separate and distinguish water according to different uses - an understanding of water's existence that does not reconcile with the connected ontology of water-as-lifeblood. This approach is entrenched in water policies at various scales, including in Federal Bill S-8 (The Safe Drinking Water Act for First Nations) and BC's new Water Sustainability Act (Provincial Bill 18, which distinguishes between various - largely settler colonial - water needs and uses). Regarding water governance in practice and in place, we observed how the installation of a drinking water treatment facility resulted in damage to existing irrigation infrastructure, in the process infringing upon livelihoods in the community and affecting the relationship between community members and the engineers implementing the project.

Conversations with community members and engineers also revealed that the newly designed water intake and canal (required for the treatment centre) also altered existing stream dynamics, thereby affecting surrounding ecosystem functions as well as a sacred body of water downstream, and consequently relegating a relational ontology of allconnecting water.

As Rasmussen (2016) has argued (in the context of irrigation development in the Andes), these divergent understanding of the effects of water management and infrastructure reflect the fact that different ways of knowing water within a particular landscape often collide, materially altering water flows and producing various water infrastructures in the process. Here, we argue that water infrastructures are equally produced by encounters among multiple water ontologies. In our example, the separation and prioritization of drinking water is only possible if we frame water as a separable resource, thereby 'cleaving apart' (Lavau, 2013) multiple water ontologies, even as they simultaneously collide in particular landscapes and in the political space of water management. In our example, this collision remains unequal, leaving a fractured politics surrounding the ontological disjuncture. ${ }^{6}$

The point here is not that we should abandon attempts to provide clean drinking water. Rather, the point is to recognize and acknowledge that the above efforts, and the policies that support them, are only made possible as part of a hegemonic ontology of water-asresource. Alternative ontologies of water, such as water-as-lifeblood, might suggest radically different policies and efforts. If we understand water to exist as a living, interconnected, and important entity for all beings, then separating drinking water 
from water as a whole might not be an accepted goal or practice in water governance. Alternative approaches would not undermine a focus on providing safe drinking water, but might rather position those efforts as one component of a broader approach to hydrosocial governance. We do not mean to suggest that water-as-lifeblood and ontologies of water-as-a-resource are inherently incompatible. However, as our example below illustrates, an ontology such as water-aslifeblood forces us to approach freshwater in fundamentally different ways (including its spatial connections) as a living being that connects and supports diverse forms of life across places.

\section{Example 2: Treating 'bounded waters' with an end-of-pipe focus}

A second example that benefits from a political ontological analysis relates to the predominance of end-of-pipe treatment approaches, which are linked to the drinking water focus of governance and are connected to a broader dominance of modernist, technological and engineering perspectives in water governance (Baker, 2013; Linton, 2010). An end-of-pipe approach further reflects (often hegemonic) ontologies of water as an entity that is understood primarily in relation to its constituents (e.g. the presence or absence of particular microbes; parts per million measures of contaminants). Partly in recognition of the limitation of end-of-pipe treatment approaches, recent trends in the field advocate source-water protection and multi-barrier approaches, effectively reducing the reliance on end-of-pipe treatment by safeguarding water in other ways (Dyck et al., 2015; Patrick, 2011). While a source-to-tap framework might remain within a modernist ontology of managing water for safe human consumption, it also reflects a more integrated approach towards social, hydrological and broader ecosystem processes. Obstacles remain to achieving an integrated source-to-tap framework, not least of which are the ontological barriers we identify here, particularly since a sourceto-tap framework defines the value of water in human terms (e.g. drinking water and a human health focus). Nonetheless, a sourceto-tap framework reflects a growing challenge to the dominance of end-of-pipe approaches, in ways that are somewhat more aligned with alternate ontologies such as water-as-lifeblood. This approach shifts focus away from treating water only where it will be used for drinking, and instead orientating management towards a concern with healthy watersheds (including a potential focus on the waterscape, including human and non-human entities that rely on water and its flows).

If we were to begin from an ontological starting point more in line with water-aslifeblood, then the separation of contaminated source water from treated (end-of-pipe) water for human consumption would appear untenable. Similar tensions have been noted in Canadian cases by the likes of Carmela Murdocca (2010) and Leanne Simpson et al. (2009). Murdocca's (2010) case revolved around a technical malfunction of the chlorine injector in Kashechewan First Nation (northern Ontario), which caused incidents of over-chlorination and a related series of endemic health problems in affected communities. According to Murdocca, government officials associated the malfunctioning chlorine injector with a lack of capacity in the Kashechewan First Nation, thereby reproducing a biopolitical form of racial governance that fails to address how these incidents are produced by broader political-historical processes of exclusion. The failed injector was also linked to the silencing and marginalizing of water-as-lifeblood 
ontologies; management proceeded with the understanding that water previously contaminated by upstream mining activities (as was the case) could simply be treated at the tap in order to provide safe drinking water. These kinds of cases - along with ongoing contamination issues in places like Grassy Narrows (Asubpeechoseewagong Netum Anishinabek First Nation) - prompted Simpson et al. (2009) to argue that water can be contaminated through the politics and history of occupation.

In these examples, we see that the very possibility of breaking water down into constituent parts and removing (or eradicating) some parts according to a treatment paradigm is only possible within the context of an ontology of water-as-a-resource, effectively undermining relational ontologies of water-as-lifeblood. Indeed, it is also possible that an end-of-pipe treatment focus might enable pollution of the source water, in the belief that such pollution can later be remedied. While such waters are deemed clean and safe according to biochemical assessments, water-as-lifeblood might otherwise stress the imperative that water begins and remains uncontaminated. Compromises cannot simply be undone through techno-scientific means, particularly given that water is an interconnected system that links humans and non-humans, which means we must recognize our limited ability to 'know' water through scientific analysis. This point also makes it clear that water-aslifeblood enhances rather than undermines drinking water requirements, as it prioritizes source-water protection over retroactive treatment.

These ontological elements also raise a spatial dynamic to the arterial flows of water-aslifeblood, which aboriginal elders have described as 'earth veins' (Anderson et al., 2013). Water as a flowing, living and connected being sustains life, not just in our bodies, but also among the ecosystems from and through which healthy water must inevitably travel. Indeed, the healthier waters are often the furthest away, and under a treatment ontology these waters become cognitively as well as spatially segregated. When disasters such as the Mount Polley tailings pond breach in British Columbia threaten healthy water supplies, consumers often still expect clear drinking water to emerge from our taps. ${ }^{7}$ Water-as-lifeblood negates this cognitive and spatial distance, as the water emerging from our taps remains contaminated even if, from a bio-chemical assessment perspective, it has been treated to the point where it is safe to drink (Cf. Simpson et al., 2009). An ontology such as water-as-lifeblood therefore raises awareness of the centrality of water as a living being, and of the relational connections that we all have with (often distant) life-sustaining waters.

As Jamie Linton has noted, it is this level of concern that has prompted objections among many First Nations in Canada to the imposition of water solutions from outside their community: often, they are opposing the rupture in a relational ontology of water, rather than the specifics of the project itself (such as the installation of treatment facilities) (Linton, 2012). Working through the implications of alternative ontologies - including water-aslifeblood - necessitates a different approach to water governance: no longer can we think of how many parts per million of a particular contaminant are deemed safe for a human body to absorb. Rather, the protection of water emerges as a primary concern. We find it interesting to note that hydrological science is increasingly moving in this direction (with a renewed focus on ecological integrity, as well as multi-barrier and one-health approaches), yet appreciating these 
issues on the level of ontological politics brings renewed meaning to their continued negotiation.

Highlighting these political-ontological dimensions also reveals some related implementation challenges for specific management practices, such as chlorination. Some small (and often remote) treatment systems rely entirely on chlorine injection to eradicate the biota and pathogens that might be harmful to human health. In larger treatment processes, chlorination is typically deployed as the final part of a three-stage process (following filtration and ultra-violet advanced oxidation). In such cases, chlorination is included primarily to prevent subsequent re-contamination of the water when travelling from the treatment plant to the point of consumption (this works both through residual chlorine and further injection at 'booster stations'). Regardless of when chlorine is added, it is non-discriminatory in terms of the living biota that it eradicates; collateral damage (the eradication of healthy bacteria, for example) is therefore inevitable. While this sacrifice may be acceptable within modernist understanding of water is made up of specific constituents (water as $\mathrm{H} 2 \mathrm{O}$ ), it might be questionable - if not untenable - according to water-as-lifeblood and similar ontologies that accept the relational interconnectedness of water as a living being.

Yet these are not binary worlds, as we discuss in the penultimate section opportunities exist to overcome persistent ontological dissonance in water governance by working at the points of interconnection and overlap among these ontological starting points. To some extent, this process has already begun, as water management approaches increasingly recognize that the microbiota of water can contribute to wellbeing and health, both for humans and other living things and ecosystem processes. Recent findings from health sciences on the importance of microbiota for wellbeing and health, for example, have shown that long-term over-use of antibiotics can accelerate the onset of Type 1 diabetes by disrupting gut bacteria (Brown et al., 2016). It is possible that recent scientific movements towards recognizing the benefits of microbiota (rather than only viewing them as harmful and to be eradicated) could offer a fundamental challenge for our water treatment processes. Such potential offers an invitation to explore more fully other possible approaches to healthful water, including those that might stem from ontologies of water itself as living. This might include better appreciation of the microbiota that may be essential to our own long-term health as well as a range of ecosystem processes.

We have encountered some of the political effects of such ontological disjunctures in our ongoing work relating to small water systems, where concerns about chlorination are often key points of contestation between engineers, operators and communities. As pointed out by the members of local communities to be served by a small-scale treatment facility, the issue was not whether chlorination is deemed scientifically safe or not (in terms of the cancer risks associated with chlorine byproducts called trihalomethanes, for instance - see Roburn, 2003), but rather why there had not been meaningful discussion about what kinds of treatment were deemed the most appropriate. What are the consequences of making these ontological assumptions without engaging the local, place-specific ontologies of water that are important for affected communities? What are the consequences of prioritising chlorination over other options? An assessment of 12 water sources in the Cree Community of Mistissini, for example, revealed that existing water harvesting and storage practices helped to 
enhance the microbiological quality of the water (microbial counts were shown to decrease upon storage) (Bernier et al., 2009). Yet the authors concluded that 'conventional' water treatment is the most appropriate solution, thereby relegating existing storage practices from the realm of effective management.

It is worth noting that objections to these kinds of approaches have been raised by both First Nations and non-First Nations members of affected communities, meaning that the issue cannot be reduced to a false dichotomy of 'Indigenous versus Western' ontologies. In addition to Linton's (2012) point that First Nations may object to chlorination due to its political imposition, rather than on the basis of questioning the scientific rationale per se, Kot et al. (2011) have shown that rural communities can also object to chlorination on the grounds that it fundamentally alters water's materiality in ways that may be both unwarranted (as UV treatment is sufficient) and not necessarily beneficial (as chlorination may undermine the benefits of bacteria-rich water and/or may have other health and ecosystem effects). These kinds of insights build on previous findings regarding the placebased, socio-cultural factors that affect socio-political relations of water (Yim, 2005), revealing that political ontological starting points might lead us to different conclusions on issues such as chlorination. Further to this, it is important to recognize that there may not be a direct, causal relation between ontologies of water-as-lifeblood and the rejection of chlorination, as local experiences and knowledge result in varied political positions regarding the varied materiality of water and its treatment. ${ }^{8}$

Our point here is not to make a judgement about the appropriateness of chlorination in diverse contexts, nor to suggest that technological treatment approaches are not valid, but rather to illustrate that there are ontological dimensions to these debates that require recognition, analysis and discussion. The debates that are needed are not simply scientific discussions (over evidence of the effects of chlorine, for example) nor questions of cultural appropriateness, but must also be understood as contestations that operate at the level of ontology. More adequate recognition of these ontological disjunctures would allow us to engage in more meaningful ways with their political implications and the possibilities for more inclusive future water governance arrangements.

Indeed, it is important to recognize that ontologies of water-as-a-resource are not inherently incapable of recognizing water as a living being. New technologies are being explored, for example, that support the microbial health of water. One such innovation, under development, aims to use metagenomics to rapidly identify what characterizes a healthy water microbiome and what characterizes one that is potentially perturbed or contaminated (Watershed Discovery, n.d.). At first glance, this example appears to be locked into the modernist, treatment ontology of which we have been critical so far. Yet it is important to recognize that such a tool also has the potential to help overcome persistent binaries between Western science and Indigenous knowledge. For example, when combined with networks of Indigenous water quality sampling and monitoring (an example of which we discuss below), a portable, fast, and inexpensive metagenomicsderived test could help First Nations to regain control over the production of knowledge on the state of their water sources. There is, therefore, a political opportunity: if we recognize that conflict may be partly ontological (rather than just cultural or epistemological), then opportunities arise for reformulating our water governance 
approaches around the notion of ontological plurality. We end the paper with some brief reflections on this point.

\section{Towards a dialogue among ontologies}

Our intention with this paper is to initiate debate on reconceiving governance arrangements if we take seriously the possibility of multiple water worlds. Given the discussion above, we argue for greater emphasis on processes of dialogue among multiple ontologies, rather than on needing to overcome 'cultural barriers' within hegemonic approaches to water governance. What might this look like in concept and practice? For the ongoing efforts to improve the situation of First Nations water in BC, we argue that engaging substantively with alternative and multiple water ontologies would necessarily entail moving beyond piecemeal reforms to recognize that 'Aboriginal water use arises in social customs as a system of water governance historically held in place through a network of localized operational, indigenous political jurisdictions' (Sam and Armstrong, 2013: 250). This recognition would produce diverse kinds of Indigenous water governance that revolve around place-based hydro-social ontologies and Indigenous hydro-social relations that 'relate directly to the social life of water as experienced in all the customs and traditions that are dependent on water' (Sam and Armstrong, 2013: 249).

As these relational hydro-social ontologies begin to be asserted in the problem space of water governance, we need new analytical approaches that recognize how ontological disjunctures shape governance frameworks and related forms of water management. One example is the notion of hydrosocial multiplicity, which stresses a repoliticization and reaffirmation of Indigenous laws, customs and knowledge in relation to water (Wilson, 2014). Prioritizing multiplicity over singularity, we argue, means engaging in dialogue among water ontologies by opening up self-enclosed Western perspectives on ontology/ontologies and engaging in processes of mutual co-learning (Bird Rose, 2008). Mutual co-learning can be fostered through 'situated engagement with ontological pluralism,' where interactions are contextualized and concepts and practices become reliant on specific circumstances for their relevance and meaning, making it possible to acknowledge multiple epistemological and ontological perspectives. In this context, Indigenous ontologies are acknowledged and respected, while critical attention is also directed towards the historical and contemporary dominance of settler-colonial approaches to governance (Howitt and Suchet-Pearson, 2006). Merrell-Ann Phare (2013: 43) described a similar process of 'two-eyed seeing', which means establishing forms of cooperation that recognize multiple kinds of ecological limits as well as the authority of Indigenous peoples.

These concepts have been applied as Indigenous water governance in practice in the Okanagan region of British Columbia, where En'owkin (or En'owkinwixw) refers to a process of consensus-making dialogue. According to Marlow Sam (2013), En'owkin is a whole systems approach that encourages the exchange of diverse perspectives; it is a philosophy that nurtures voluntary cooperation and which recognizes that existing life forms have status, rights and privileges that are equal to humans, and which must be protected (Sam, 2013). It encapsulates the notion of water as siwlkw - of water as a morethan-human processes of emergence, rather than simply a resource available for 
consumption (Armstrong, 2013). En'owkin therefore necessitates the inclusion of diverse ontologies and the development of integrated approaches that are based on those diverse ontologies, thereby benefiting human populations and ecosystems as a whole (Sam, 2013). En'owkin is the kind of plural ontology we hope to foreground, and it is an approach that has been successful in protecting and preserving hydrologic environments for many in the Okanagan valley (Sam, 2008). For Sam, the success of the approach relates specifically to its relational perspective, as human and natural rights are conceived as inter-dependent, meaning that one cannot exist without the other. Thus, any discussion of indigenous rights or a human right to water must inevitably also engage with the rights of nature and water. New and emerging governance arrangements, we argue, must not only acknowledge these relational ontologies, but rather should treat them as a foundation alongside any other (hegemonic) ontologies that have shaped our water practices to date. ${ }^{9}$

Similar concepts have been applied by other First Nations in BC, such as Nuuyum - a placed-based Haisla ontology and a contextual set of reciprocal relations among the land, water, history and everyone involved (Green, 2015). Examples also exist elsewhere, including the relational ethic of the Ngai Tahu's (a Maori iwi tribe) engagement with the Hurunui River in New Zealand, which has helped to reorient governance of the Hurunui River and to challenge the dominance of instrumentalist approaches (Thomas, 2015). As Thomas (2015) points out, however, part of the challenge is to avoid simply resorting to the discourse and language of Western science, instead enabling conversations that articulate kinship relations with water and water bodies. Connecting these kinds of place-based principles and practices through diverse forms of language and representation may help to produce a broader dialogue among water ontologies.

We suggest that one approach to such connection might be to learn from experiences such as the Coastal Stewardship Network - a regional monitoring system based on a network of First Nations stewards (sometimes called 'guardian watchmen') who collect their own data for their own resource planning, management and decisionmaking purposes (Kotaska, 2013). The Network helps to coordinate local stewardship offices, each of which is engaged in its own, contextual processes of environmental monitoring. Similarly, the Coast Salish Gatherings documented by Emma Norman (2014) offer a useful case for understanding how to connect across politically imposed boundaries by asserting the ontological status of the Salish Sea, and casting the Salish coastal region as a politicalontological actor within scalar political debates that address issues such as pollution and resource pressure (Norman, 2012, 2014). While not without their own limitations that require analysis, in both of these cases diverse ontologies of water are being asserted and connected within new coastal governance processes.

Similar approaches might be developed in relation to freshwater. One option might be to build on the emerging network of Indigenous water operators in BC and the Yukon, which was launched in October 2015. Until recently, the water operators - who are trained within the 'Circuit Rider Training Program' managed by Aboriginal Affairs and Northern Development Canada (AANDC; now Indigenous and Northern Affairs Canada, INAC) - have largely acted in a technical capacity to maintain water infrastructure. Building on this training programme, however, First Nations operators in 
British Columbia and the Yukon Territory have also been working to overcome what they perceive to be a lack of crosscontext learning and capacity building. Questions remain as to the role that the network will play in regional water governance, especially given its basis upon technical approaches to water management and its ties to AANDC/INAC. Nonetheless, if the network articulates itself politically in a similar fashion to the Coastal Stewardship Network or the Coast Salish Gatherings, or if it supports an affiliated network of freshwater monitoring and stewardship, then it could help to establish the kinds of regional governance and monitoring systems that build upon rather than subvert - multiple water ontologies. Such networks are beginning to emerge in practice in other contexts as well, including the Yukon River Inter-Tribal Watershed Council (YRITWC) - a grassroots organization based on a treaty between 73 Indigenous governments from Yukon Territory and British Columbia in Canada and Alaska in the US (Wilson, 2014). The question for freshwater in BC is whether similar networked articulations of diverse ontologies and alternative governance arrangements will be enabled to affect decision- and policy-making processes increasingly in the future.

\section{CONCLUSION}

In ending the paper with the above examples of reformulated water governance in practice, we hope to illustrate the utility of bringing together insights from the ontological turn and from the study of water. Conceptually, ontological perspectives help to move analysis beyond a focus on issues such as alternative knowledge systems, which may not have led us to the above examples and would have risked dismissing alternative ontologies as cultural constructs. Water as siwlkw, for example, is not simply an alternative construction of water, as it is the lived reality of the Okanagan peoples. To dismiss it as simply a cultural construct would be similar to dismissing $\mathrm{H} 2 \mathrm{O}$ as just a cultural product of Western science, when in fact there is an ontological acceptance of the materiality entailed in the hydrogen and oxygen bonds. An ontological approach asks whether the materiality of water as siwlkw, for example, should be similarly accepted, rather than continually challenged and undermined by hegemonic modernist ontologies. We argue that this conclusion is different to one that might be reached if we were to focus on incorporating Okanagan knowledge systems into modernist understanding of water - an approach that would risk further entrenching hegemonic ontologies.

Practically, a key insight brought by ontological perspectives is the need to open up established - and arguably hegemonic - approaches to environmental governance. While contributors such as Blaser have illustrated how governance approaches can fail if we ignore ontological issues, we have focussed on what a multiple ontological perspective can bring to water governance by pluralizing both our understanding of what water is and our ideas of Yates et al. 13 what management and governance entail. The examples in the penultimate section show that new forms of governance are already emerging, and that they can better attend to multiple and diverse engagements with water as a living being. These approaches need not undermine established practices of safeguarding water, but they are required in order to destabilize a 
hegemonic ontology of water-as-a-resource, which continues to break down water and to undermine water as a living being.

Finally, the study of water also sheds new light on ontological debates, not least because water's fluid materiality brings a new spatial element. While Annemarie Mol's approach shed light on a corporeal spatiality - on the potential for a diverse body politics - our water examples connect ontological issues across scales. Just as Steinberg and Peters (2015) have drawn attention to a voluminous and deep wet (ocean) ontology, here we seek to emphasize a flow-oriented and connecting ontology of freshwater (which we might conceive as arterial), as expressed through water-aslifeblood. As such, healthy water flows are dependent on source-water protection (at the heart) and cannot be reduced to end-of-pipe approaches that disconnect water consumption from ecological relations. As Neimanis (2013) has argued, recognizing these inherent links means that we must (re)configure ourselves as bodies of water in order to understand how an uneven hydro-politics affects different bodies in variable ways. Thus the study of water brings new political dimensions to ontological debates, as it extends the concern beyond individual conservation practices, for example, to instead necessitate the connection of different people, places and ontologies. The study of water therefore prompts the kinds of dialogues among ontologies that we have highlighted here, and which we hope will become of increasing interest across environmental governance realms.

\section{Declaration of conflicting interests}

The author(s) declared no potential conflicts of interest with respect to the research, authorship, and/or publication of this article.

\section{Funding}

The author(s) disclosed receipt of the following financial support for the research, authorship, and/or publication of this article: Funding for this work was provided by the Social Science and Humanities Research Council (SSHRC) of Canada ("Water Economics, Policy and Governance Network" project) and the Natural Science and Engineering Research Council (NSERC) of Canada ("RES' EAU WaterNET" project).

\section{Notes}

1. The term First Nations is one of three commonly used in Canada to refer to Indigenous peoples (the other two are Me'tis and Inuit). According to Indigenous and Northern Affairs Canada (INAC) there are more than 50 recognized First Nations across Canada. Diversity exists between and within these Nations, and our purpose in this paper is not to attempt a characterization of one or multiple First Nations ontologies (cf. Hunt, 2014). Rather, we are interested in the general issue of ontological disjunctures, exposing the contested politics that result. In also drawing on examples from outside of Canada, we use the term Indigenous to refer to Aboriginal peoples from around the world. 
2. We focus on the influence of the ontological turn in geography and environmental governance, but for a review of the ontological turn in cultural anthropology - a sub-discipline in which these interventions have been particularly pronounced see Henare et al. (2007) and Paleček and Risjord (2013).

3. Space constraints prevent a comprehensive discussion of the literature considered part of the 'ontological turn'; we focus on examples that we think best support our approach and argument.

4. In contrasting a water-as-a-resource paradigm to water-as-lifeblood, we do not mean to imply that a simple and fixed binary exists between 'Western' (or modern) and 'Indigenous' world views and/or ontologies, that ontologies are fixed, or that water governance paradigms could simply incorporate Indigenous ontologies. While many of the examples we draw on are from contributions made by or in collaboration with Indigenous scholars, our goal is not to depict any one 'Indigenous ontology' (cf. Hunt, 2014). We also acknowledge the limitations of our perspective as non-Indigenous scholars, who cannot claim to 'know' Indigenous water ontologies. It is also worth noting that Indigenous thinkers have largely been marginalized from debates within the 'ontological turn' to date, despite having long-stressed relational ontologies and relationality broadly (Atleo, 2011; Manson, 2015; Rivera Cusicanqui, 2012; Todd, 2014). Our aim is not to perpetuate this process by appropriating Indigenous ontologies, but rather to help build the language for engaging with the ontological issues in question (see Thomas, 2015).

5. Consistent with a relational ontology of water, First Nations often focus on responsibilities for protecting water (e.g. Anderson et al., 2013, specifically discuss the responsibilities of First Nations women across Canada). Yet, Indigenous peoples strategically engage the language of 'rights', a legal term conceptualized by settler governments, to assert both rights and responsibilities to water (Castleden et al., 2017). Despite growing acknowledgement of First Nations rights and title in Canada, and the deployment of those rights among First Nations to challenge dominant ontologies, Aboriginal rights to water (and any related rights of water that may be associated with alternative water ontologies) are considered legally ambiguous because they have never been explicitly established or disproven through a court ruling in Canada (Phare, 2009; Simms et al., 2016). Although it is not the purpose of this paper to discuss the relationship between Indigenous governance and ontologies comprehensively, we note that the failure of settler colonial governments to acknowledge First Nation water rights within their territories poses a political barrier to asserting source-water protection plans in ways that are consistent with First Nations' diverse relationships to water (e.g. water-as-lifeblood and others).

6. We do not mean to imply that simply attending to irrigation would solve the problem in this example. The issue stems from a fundamentally different way of being with water, which is oriented around connection rather than separation. Such possibilities are generally not considered as part of treatment projects.

7. In August 2014, up to 25 million cubic metres of contaminated water and mine waste spilled into lakes and waterways from a tailings pond (a reservoir of mining 
effluents) operated by Imperial Metals at the Mount Polley copper and gold mining site, located in the Caribou region of British Columbia, Canada.

8. There is a spatial dynamic to the material-affective relation here, as 'healthy' bacteria for some may be harmful to others, particularly between different places. This complicates the spatial dynamics of an ontological politics - an element that is worth exploring, but which we cannot foreground here due to space constraints.

9. It is worth noting that En'owkin is neither specific to water, nor reducible to governance per se; it is a principle that upholds life and is not synonymous with Western notions of governance as sectorspecific decision-making processes.

\section{REFERENCES}

Anderson K, Clow B and Haworth-Brockman M (2013) Carriers of water: Aboriginal women's experiences, relationships, and reflections. Journal of Cleaner Production 60: $11-17$.

Armstrong J (2013) Water is Siwlkw. In: Chen C, MacLeod J and Neimanis A (eds) Thinking with Water. Montreal: McGill-Queen's University Press, pp. 104-105. Atleo ER (2011) Principles of Tsawalk: An Indigenous Approach to Global Crisis. Vancouver: UBC Press.

Baker LA (2013) Hegemonic concepts and water governance from a scientific engineering perspective. In: Harris L, Goldin J, Sneddon C, , et al. (eds) Contemporary Water Governance in the Global South: Scarcity, Marketization and Participation. Abingdon: Routledge, pp. 25-32.

Bakker K (2012) Water: Political, biopolitical, material. Social Studies of Science 42: 616-623.

Barad KM (2007) Meeting the Universe Halfway: Quantum Physics and the Entanglement of Matter and Meaning. Durham, NC: Duke University Press.

Barnes J and Alatout S (2012) Water worlds: Introduction to the special issue of social studies of science. Social Studies of Science 42: 483-488.

Basdeo M and Bharadwaj L (2013) Beyond physical: Social dimensions of the water crisis on Canada's First Nations and considerations for governance. Indigenous Policy Journal 23: 1-14.

Bear C (2012) Assembling the sea: Materiality, movement and regulatory practices in the Cardigan Bay scallop fishery. Cultural Geographies 20: 21-41.

Bear C and Bull J (2011) Guest Editorial. Environment and Planning A 43: 2261-2266. 
Bernier JLT, Maheux AF, Boissinot M, et al. (2009) Onsite microbiological quality monitoring of raw source water in Cree community of Mistissini. Water Quality Research Journal of Canada 44: 345-354.

Bird Rose D (2008) On history, trees, and ethical proximity. Postcolonial Studies 11: 157-167.

Biro A (2013) River-adaptiveness in a globalized world. In: Chen C, MacLeod J and Neimanis A (eds) Thinking with Water. Montreal: McGill-Queen's University Press, pp. 166-184.

Blackstock M (2001) Water: A First Nations' spiritual and ecological perspective. BC Journal of Ecosystems and Management 1: 2-14.

Blaser M (2009a) Political ontology. Cultural Studies 23: 873-896.

Blaser M (2009b) The threat of the Yrmo: The political ontology of a sustainable hunting program. American Anthropologist 111: 10-20.

Blaser M (2013) Ontological conflicts and the stories of peoples in spite of Europe:

Toward a conversation on political ontology. Current Anthropology 54: 547-568.

Blaser M (2014) Ontology and indigeneity: On the political ontology of heterogeneous assemblages. Cultural Geographies 21: 49-58.

Boelens R (2014) Cultural politics and the hydrosocial cycle: Water, power and identity in the Andean highlands. Geoforum 57: 234-247.

Brown K, Godovannyi A, Ma C, et al. (2016) Prolonged antibiotic treatment induces a diabetogenic intestinal microbiome that accelerates diabetes in NOD mice. ISME Journal 10: 321-332.

Castleden H, Hart C, Cunsolo A, et al. (2017) Reconciliation and relationality in water research and management in Canada: Implementing indigenous ontologies, epistemologies, and methodologies. In: Renzetti S and Dupont DP (eds) Water Policy and Governance in Canada. Basel: Springer International, pp. 69-95.

Chen C, MacLeod J and Neimanis A (2013a) Introduction. In: Chen C, MacLeod J and Neimanis A (eds) Thinking with Water. Montreal: McGill-Queen's University Press, pp. 3-22.

Chen C, MacLeod J and Neimanis A (2013b) Thinking with Water. Montreal: McGillQueen's University Press.

Cruikshank J (2004) Do Glaciers Listen?: Local Knowledge, Colonial Encounters, and Social Imagination. Vancouver: UBC Press. 
de La Cadena M (2010) Indigenous cosmopolitics in the Andes: Conceptual reflections beyond "politics". Cultural Anthropology 25: 334-370.

de la Cadena M (2015) Earth Beings: Ecologies of Practice Across Andean Worlds. Durham, NC: Duke University Press.

Dyck T, Plummer R and Armitage D (2015) Examining First Nations' approach to protecting water resources using a multi-barrier approach to safe drinking water in Southern Ontario, Canada. Canadian Water Resources Journal 40: 204-223.

Forsyth T and Levidow L (2015) An ontological politics of comparative environmental analysis: The green economy and local diversity. Global Environmental Politics 15: $140-151$.

Green J (2015) Transforming our nuuyum: Contemporary Indigenous leadership and governance. Indigenous Law Journal 12: 33-60.

Harris L (2015) Hegemonic waters and rethinking natures otherwise. In: Harcourt W and Nelson IL (eds) Practising Feminist Political Ecologies: Moving Beyond the 'Green Economy'. London: Zed Books, pp. 157-181.

Harris L, Goldin J, Sneddon C, et al. (2013) Contemporary water governance in the global south: Scarcity, marketization and participation. Abingdon: Routledge.

Hastrup K and Hastrup F (2016) In: Hastrup K and Hastrup F (eds), Waterworlds: Anthropology in Fluid Environments, Ethnography, Theory, Experiment. Berghahn Books, NY: Berghahn Books.

Henare A, Holbraad M and Wastell S (2007) Thinking Through Things: Theorising Artefacts Ethnographically. New York, NY: Routledge.

Hirsch E (2017) Investment's rituals: "Grassroots" extractivism and the making of an indigenous gold mine in the Peruvian Andes. Geoforum. volume 81. DOI:

http://dx.doi.org/10.1016/j.geoforum. 2016.08.012.

Howitt R and Suchet-Pearson S (2006) Rethinking the building blocks: Ontological pluralism and the idea of 'management'. Geografiska Annaler: Series B, Human Geography 88: 323-335.

Hunt S (2014) Ontologies of Indigeneity: The politics of embodying a concept. Cultural Geographies 21: 27-32.

Jollymore A, McFarlane K and Harris LM (2017) Whose input counts? Evaluating the process and outcomes of public consultation through the BC Water Act Modernization. Critical Policy Studies Forthcoming: 1-25. DOI: 10.1080/19460171.2017.1282377. 
Joronen M and Ha"kli J (2016) Politicizing ontology. Progress in Human Geography. Epub ahead of print 2016. DOI: 10.1177/0309132516652953.

Kesler L (n.d.) Aboriginal Identity \& Terminology. Available at:

http://indigenousfoundations.arts.ubc. ca/home/identity/aboriginal-identityterminology.html (accessed 13 February 2017).

Kot M, Castleden $\mathrm{H}$ and Gagnon GA (2011) Unintended consequences of regulating drinking water in rural Canadian communities: Examples from Atlantic Canada. Health Place 17: 1030-1037.

Kotaska JG (2013) Reconciliation 'at the end of the day': Decolonizing territorial governance in British Columbia after Delgamuukw (Doctor of Philosophy). Institute for Resources, Environment, and Sustainability. Vancouver: University of British Columbia. Available at: https://circle.ubc.ca/ handle/2429/45003.

Krause F and Strang V (2016) Thinking relationships through water. Society \& Natural Resources 29: 633-638.

LaBoucane-Benson P, Gibson G, Benson A, et al. (2012) Are w seeking Pimatisiwin or creating Pomewin? Implications for water policy. International Indigenous Policy Journal 3.

Lavau S (2013) Going with the flow: Sustainable water management as ontological cleaving. Environment and Planning D: Society and Space 31: 416-433.

Li F (2013) Contesting equivalences: Controversies over water and mining in Peru and Chile. In: Wagner JR (ed.) The Social Life of Water. New York, NY: Berghahn, pp. 1835.

Linton J (2010) What is Water?: The History of a Modern Abstraction. Vancouver: UBC Press.

Linton J (2012) The human right to what? Water, rights, humans, and the relation of things. In: Sultana F and Loftus A (eds) The Right to Water: Politics, Governance and Social Struggles. London: Earthscan, pp. 45-60.

Linton J and Budds J (2014) The hydrosocial cycle: Defining and mobilizing a relationaldialectical approach to water. Geoforum 57: 170-180.

Loftus A (2007) Working the socio-natural relations of the urban waterscape in South Africa. International Journal of Urban and Regional Research 31: 41-59.

Lorimer $\mathrm{H}$ (2006) Herding memories of humans and animals. Environment and Planning D: Society and Space 24: 497-518. 
Manson J (2015) Relational Nations: Trading and sharing ethos for Indigenous food sovereignty on Vancouver Island. Vancouver: University of British Columbia.

McGregor D (2012) Traditional knowledge: Considerations for protecting water in Ontario. International Indigenous Policy Journal 3: 1-21.

Mehta L (2013) Water and ill-being: Displaced people and dam-based development in India. In: Wagner J (ed.) The Social Life of Water. New York: Berghahn Books, pp. 6179.

Mol A (1999) Ontological politics. A word and some questions. The Sociological Review 47: 74-89.

Mol A, Smith BH and Weintraub ER (2002) The Body Multiple. Durham, NC: Duke University Press.

Murdocca C (2010) "There is something in that water": Race, nationalism, and legal violence. Law \& Social Inquiry 35: 369-402.

Nadasdy P (2007) The gift in the animal: The ontology of hunting and human-animal sociality. American Ethnologist 34: 25-43.

Neimanis A (2013) Feminist subjectivity, watered. Feminist Review 103: 23-41.

Nightingale AJ (2016) Adaptive scholarship and situated knowledges? Hybrid methodologies and plural epistemologies in climate change adaptation research. Area 48: $41-47$.

Norman E (2012) Cultural politics and transboundary resource governance in the Salish sea. Water Alternatives 5: 138-160.

Norman E (2014) Governing Transboundary Waters Canada, the United States and Indigenous Communities. London: Routledge Press.

Palec ${ }^{2}$ k M and Risjord M (2013) Relativism and the ontological turn within anthropology. Philosophy of the Social Sciences 43: 3-23.

Patrick RJ (2011) Uneven access to safe drinking water for First Nations in Canada: Connecting health and place through source water protection. Health Place 17: 386389.

Phare M-AS (2009) Denying the Source: The Crisis of First Nations Water Rights. Surrey, BC: Rocky Mountain Books.

Phare M-AS (2011) Restoring the Lifeblood: Water, First Nations and Opportunities for Change: Background Report. Toronto: Walter and Duncan Gordon Foundation. 
Phare M-AS (2013) Indigenous peoples and water: Governing across borders. In: Norman ES and Bakker K (eds) Water Without Borders? Canada, the United States, and Shared Water. Toronto: University of Toronto Press, pp. 27-46.

Rasmussen MB (2016) Water futures: Contention in the construction of productive infrastructure in the Peruvian Highlands. Anthropologica 58: 211-226.

Rivera Cusicanqui S (2012) "Ch'ixinakax utxiwa": A reflection on the practices and discourses of decolonization. South Atlantic Quarterly 111: 95-109.

Roburn S (2003) Chlorine conflict. Alternatives Journal 29: 26. Sam M (2008) Okanagan Water Systems: An Historical Retrospect of Control, Domination and Change. Vancouver: University of British Columbia.

Sam M (2013) Oral Narratives, Customary Laws and Indigenous Water Rights in Canada. Vancouver: University of British Columbia.

Sam M and Armstrong J (2013) Indigenous water governance and resistance: A syilx perspective. In: Wagner $\mathrm{J}$ (ed.) The Social Life of Water. New York: Berghahn Books, pp. 239-253.

Simms R, Harris L, Joe N, et al. (2016) Navigating the tensions in collaborative watershed governance: Water governance and Indigenous communities in British Columbia, Canada. Geoforum 73: 6-16. doi: http://dx.doi.org/10.1016/i.geoforum.2016.04.005.

Simpson L, DaSilva J, Riffel B, et al. (2009) The responsibilities of women: Confronting environmental contamination in the traditional territories of Asubpeechoseewagong Netum Anishinabek (Grassy Narrows) and Wabauskang First Nation. Journal of Aboriginal Health 4: 6-13.

Sneddon C (2013) Water, governance, and hegeony. In: Harris L, Goldin J, Sneddon C, et al. (eds) Contemporary Water Governance in the Global South: Scarcity, Marketization and Participation. Abingdon: Routledge, pp. 13-24.

Spiegel JB (2013) Subterranean flows: Water contamination and the politics of visibility after the Bhpoal disaster. In: Chen C, MacLeod J and Neimanis A (eds) Thinking with Water. Montreal: McGill-Queen's University Press, pp. 84-103.

Steinberg P and Peters K (2015) Wet ontologies, fluid spaces: Giving depth to volume through oceanic thinking. Environment and Planning D: Society and Space 33: 247264.

Stensrud AB (2016) Climate change, water practices and relational worlds in the Andes. Ethnos 81: 75-98. 
Strang V (2004) The Meaning of Water. Oxford: Berg.

Sundberg J (2014) Decolonizing posthumanist geographies. Cultural Geographies 21: 33-47.

Swyngedouw E (1999) Modernity and hybridity: Nature, regeneracionismo, and the production of the Spanish waterscape, 1890-1930. Annals of the Association of American Geographers 89: 443-465.

Thomas AC (2015) Indigenous more-than-humanisms: Relational ethics with the Hurunui River in Aotearoa New Zealand. Social \& Cultural Geography 16: 974-990.

Todd Z (2014) Fish pluralities: Human-animal relations and sites of engagement in Paulatuuq, Arctic Canada. Etudes Inuit. Inuit Studies 38: 217-238.

Wagner JR (2013) The Social Life of Water. New York, NY: Berghahn Books.

Walkem A(2004), Lifeblood of the Land: Aboriginal Peoples' Water Rights in British Columbia. Surrey, BC: Environmental Aboriginal Guardianship through Law and Education.

Watershed Discovery (n.d.) Metagenomics: Window on Microbial Biodiversity. Available at: http:// www.watersheddiscovery.ca/?portfolio1/4metagenomics (accessed 23 October 2016).

Wilson NJ (2014) Indigenous water governance: Insights from the hydrosocial relations of the Koyukon Athabascan village of Ruby, Alaska. Geoforum 57: 1-11.

Yim Y (2005) Public Perceptions of Drinking Water Risk: A Community Perspective. Prince George: University of Northern British Columbia. 